National Marine

Fisheries Service

NOAA
Fishery Bulletin

a established in 1881 a
Spencer F. Baird

First U.S. Commissione of Fisheries and founder of Fishery Bulletin

\begin{abstract}
For anadromous Pacific salmon (Oncorhynchus sp.), ocean conditions during their initial entry into the marine environment can greatly affect their survival. Different life history types or stocks may experience different conditions during their marine entry because routes of early marine migration can differ among types or stocks. Steelhead (O. mykiss) from the Columbia River are believed to migrate offshore quickly once they enter the ocean, but little is known about whether life history or stock-specific differences in early marine migration exist. We assembled a baseline of steelhead genetic data that allowed us to estimate the genetic stock of origin for juvenile steelhead that had been caught off the coasts of Washington and Oregon in May, shortly after their out-migration from freshwater. We found differences in the average locations of the various genetic stock groups of the Columbia River, dissimilarities that were most likely due to differences in the timing of the marine entry of juveniles. We also observed considerable variation among years in the average location where we caught steelhead and in the number of steelhead caught, results indicating that freshwater or marine conditions can influence the behavior or survival of steelhead.
\end{abstract}

Manuscript submitted 25 July 2018. Manuscript accepted 11 April 2019.

Fish. Bull. 117:97-106 (2019).

Online publication date: 26 April 2019. doi: 10.7755/FB.117.1-2.11

The views and opinions expressed or implied in this article are those of the author (or authors) and do not necessarily reflect the position of the National Marine Fisheries Service, NOAA.

\title{
Insights, from genetic analyses, into stock-specific distribution of juvenile steelhead (Oncorhynchus mykiss) from the Columbia River during early marine migration
}

\author{
Donald M. Van Doornik (contact author)' \\ David R. Kuligowski1 \\ Cheryl A. Morgan² \\ Brian J. Burke ${ }^{3}$ \\ Todd R. Seamons 4 \\ Email address for contact author: don.vandoornik@noaa.gov \\ ${ }^{1}$ Conservation Biology Division \\ Northwest Fisheries Science Center \\ National Marine Fisheries Service, NOAA \\ 7305 Beach Drive East \\ Port Orchard, Washington 98366 \\ 2 Cooperative Institute for Marine Resources \\ Studies \\ Hatfield Marine Science Center \\ 3 Fish Ecology Division \\ Northwest Fisheries Science Center \\ National Marine Fisheries Service, NOAA \\ 2725 Montlake Boulevard East \\ Seattle, Washington 98112 \\ ${ }^{4}$ Washington Department of Fish and Wildlife \\ 1111 Washington Street Southeast \\ Olympia, Washington 98501
}

Oregon State University

2030 South Marine Science Drive

Newport, Oregon 97365
Anadromous Pacific salmon (Oncorhynchus sp.) utilize the marine environment for rapid growth to maturity. Results of studies have indicated that the initial months after entry into saltwater are important to the survival of steelhead and that this time period affects year-class strength (Pearcy, 1992; Hare and Francis, 1995). Therefore, understanding their marine distribution and migration, and how they respond to different marine conditions during those initial months, can provide knowledge of the variables that contribute to strong year classes.

The Columbia River is home to several species of salmonids, many of which have been listed as threatened or endangered under the U.S. Endangered Species Act, including steelhead (Oncorhynchus mykiss). Steelhead are the life history variant of $O$. mykiss that migrate from their place of birth in freshwater to the ocean, where they remain for several years before returning to their river of origin to spawn. For steelhead from the Columbia River Basin, populations in the Lower, Middle, and Upper Columbia, Upper Willamette, and Snake Rivers are listed as threatened (NWFSC, 2015). Despite the imperiled status of these populations, the greatest number of steelhead in the Pacific Northwest are produced in the Columbia River (Busby et al., 1996), contributing significantly to highly valued recreational and tribal fisheries throughout the region.

The Columbia River contains 2 phylogenetic groups (subspecies) of steelhead that are separated by the Cascade Mountain Range: coastal steelhead (O. mykiss irideus) and Columbia River redband steelhead (O. mykiss gairdnerii), the latter 


\section{Table 1}

Genetic stock groups and run types of the 148 populations of steelhead (Oncorhynchus mykiss) used in genetic stock identification analyses in this study of the early marine migration of steelhead from the Columbia River. The 2 phylogenetic groups or subspecies of steelhead are coastal steelhead (O. mykiss irideus) and Columbia River redband steelhead (O. mykiss gairdnerii), commonly referred to as inland steelhead.

\begin{tabular}{lccc}
\hline Genetic stock group & $\begin{array}{c}\text { Phylogenetic } \\
\text { group }\end{array}$ & $\begin{array}{c}\text { No. of } \\
\text { populations }\end{array}$ & Run type \\
\hline Puget Sound/Strait of Juan de Fuca & Coastal & 12 & Winter \\
Washington coast & Coastal & 7 & Winter \\
Lower Columbia River summer run & Coastal & 4 & Summer \\
Lower Columbia River winter run & Coastal & 17 & Winter \\
Middle and Upper Columbia River/Lower Snake River & Inland & 67 & Summer \\
Middle and Upper Snake River & Inland & 28 & Summer \\
Oregon coast & Coastal & 7 & Summer, winter \\
Klamath Mountains Province & Coastal & 3 & Summer, winter \\
Northern California & Coastal & 2 & Summer, winter \\
Central Valley, California & Coastal & 1 & Winter \\
& & & \\
\hline
\end{tabular}

of which is commonly referred to as inland steelhead (Busby et al., 1996; Blankenship et al., 2011). Within these groups, there are 2 life history types that are identified by the time of year when they return to freshwater and by their maturity status when they arrive in freshwater. The inland group is composed almost exclusively of summer-run steelhead (Busby et al., 1996). These are stream-maturing steelhead that enter freshwater between May and October, when they are still sexually immature, and remain in freshwater for several months until they mature and spawn. Summerrun stocks are present also in populations of coastal steelhead, but this group is primarily composed of winter-run steelhead. Winter-run steelhead are oceanmaturing fish that enter freshwater between November and April almost fully mature, and they spawn shortly after entry into a river.

Steelhead of the Columbia River out-migrate from freshwater to saltwater through the Columbia River estuary in springtime, with peak out-migration occurring in mid-May (Weitkamp et al., 2012; Weitkamp et al., 2015). They travel through the estuary quickly (Dawley et al., 1986) and, after reaching the marine environment, move quickly into offshore waters before heading north to the Gulf of Alaska (Burgner et al., 1992; Brodeur et al., 2004; Quinn and Myers, 2004; Daly et al., 2014). This movement contrasts with that of other salmonids, such as Chinook (Oncorhynchus tshawytscha) and coho (O. kisutch) salmon, which remain closer to the coast as they migrate northward (Van Doornik et al., 2007; Teel et al., 2015). The rapid offshore migration of steelhead could be related to a need to quickly travel to areas where the fish larvae on which they prey are more abundant (Daly et al., 2014). However, it is not known if there are stock-specific differences in routes of early marine migration.

Variation among individuals in migration routes can affect survival (Furey et al., 2015), and, if differences in migration routes among stocks exist, factors, such as oceanographic conditions, hatchery practices, or management of water flow through the hydroelectric dams of the Columbia River, could affect the survival of different stocks in different ways. Therefore, our goals for this study were to determine if there are differences in the early marine migration of steelhead among genetic stock groups and if any such differences vary from year to year.

\section{Materials and methods}

\section{Sample collection and genotyping}

To estimate the genetic stock to which each juvenile steelhead belonged, we first had to create a baseline of genotypic data for steelhead populations whose members were likely to be found in our study area. No such baseline existed; therefore, we compiled genotypic data collected by several genetics laboratories based on the West Coast of the United States. Data for populations of Puget Sound, the Strait of Juan de Fuca, and the Washington coast were provided by the Washington Department of Fish and Wildlife (T. Seamons, unpubl. data). Data for steelhead of the Columbia River were obtained from the Columbia River Inter-Tribal Fish Commission and Idaho Department of Fish and Game (data available from website, accessed January 2016; Hess et al.1; Matala et al., 2014). The NOAA Northwest

\footnotetext{
${ }^{1}$ Hess, J. E., N. R. Campbell, A. P. Matala, and S. R. Narum. 2013. 2012 annual report: genetic assessment of Columbia River stocks, 147 p. Div. Fish Wildl., Bonneville Power Admin., U.S. Dep. Energy, Portland, OR [Available from website, accessed July 2018.]
} 


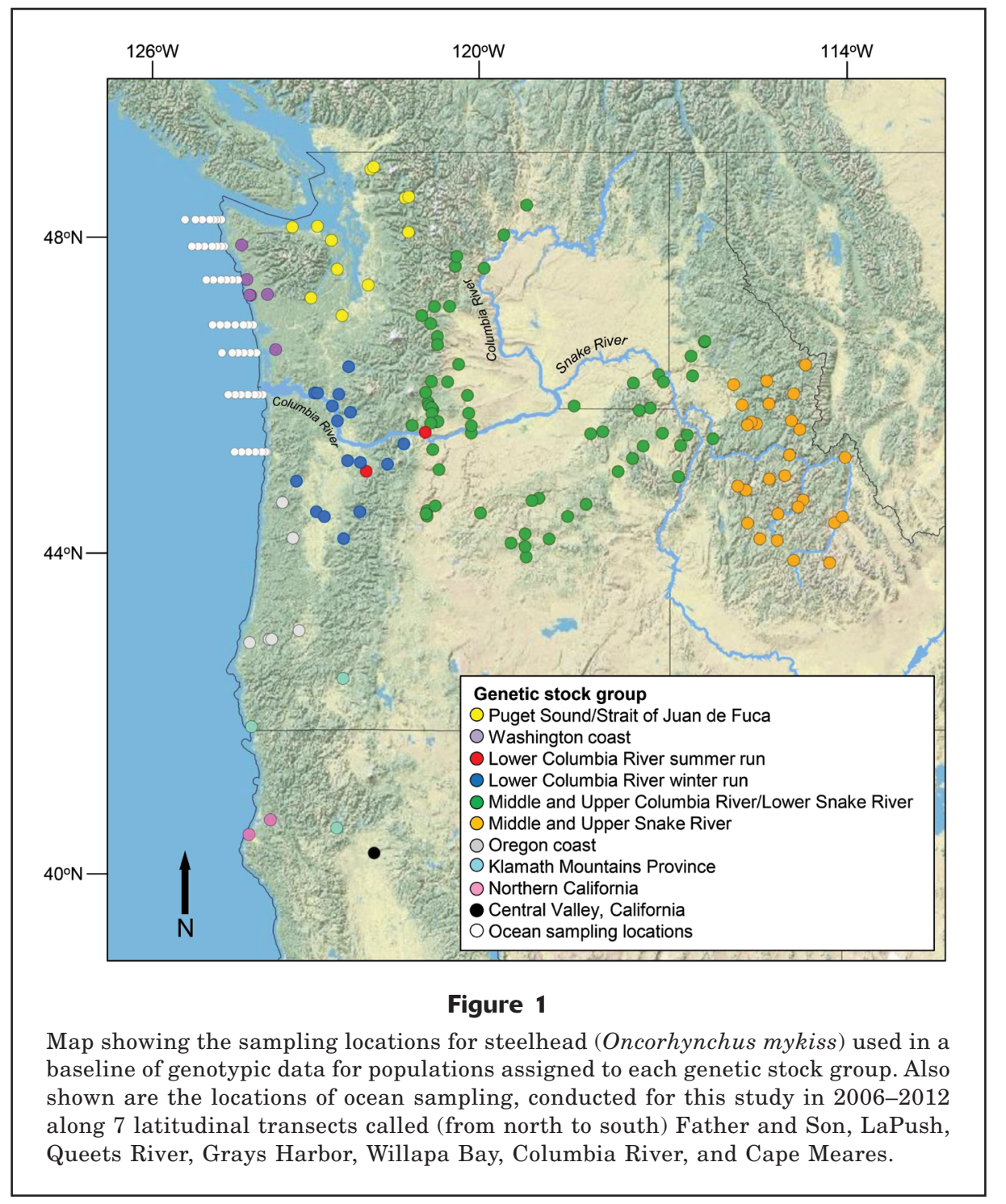

Fisheries Science Center collected genotypes for samples collected from coastal rivers of Oregon and California (data available from website, accessed December 2017). The compiled baseline consisted of genotypes of 9934 steelhead from 148 populations (Table 1, Fig. 1).

Ocean-caught samples were obtained as part of a much larger project studying the early marine ecology of salmon from the Columbia River (Brodeur et al., 2000; Brodeur et al., 2005). The steelhead samples used in this study were collected from trawl hauls made in May in each year of the period 2006-2012. Sampling was conducted off the coasts of Washington and Oregon along 7 transects, from $48^{\circ} 13.7^{\prime} \mathrm{N}$ to $45^{\circ} 29.0^{\prime} \mathrm{N}$ (Fig. 1), by towing a Nordic 264-rope trawl (Nor'Eastern Trawl Systems, Inc. ${ }^{2}$, Bainbridge Island, WA) at a

\footnotetext{
${ }^{2}$ Mention of trade names or commercial companies is for identification purposes only and does not imply endorsement by the National Marine Fisheries Service, NOAA.
}

speed of approximately $1.6 \mathrm{~m} / \mathrm{s}$ for $30 \mathrm{~min}$ (Brodeur et al., 2005). The same vessel, gear, trawling depth, and speed were implemented each year. At the time of capture, fish were identified to species, measured (in fork length), and then frozen on board the sampling vessel. In the laboratory, fish were thawed, re-measured, and examined for marks indicating hatchery origin, such as adipose fin clips or coded-wire tags, and a portion of their caudal fin tissue was preserved in $100 \%$ ethanol.

Procedures for genotyping samples differed slightly among the laboratories contributing data to this project, but all were similar to the method described by Hess et al. ${ }^{1}$. In general, fish were genotyped for 131 or 180 single nucleotide polymorphism (SNP) loci (Hess et al. ${ }^{1}$ ) by amplifying loci of interest through the use of polymerase chain reactions (PCR). The resulting PCR products were then visualized by using genotyping platforms from either Fluidigm Corp. (South San Francisco, CA) or Illumina, Inc. (San Diego, CA). 


\section{Genetic stock identification}

Estimates of the stock of origin for each fish were made by using genetic stock identification (GSI). To perform GSI, we used the algorithms employed by the software ONCOR (Kalinowski et al., 2007). The ONCOR program uses the partial-Bayesian algorithms of Rannala and Mountain (1997) with an expectation maximization algorithm to assign individuals to their most likely population of origin by using a baseline of genetic information collected from samples of known origin. A critical assumption of this method is that all possible source populations are in the baseline. This assumption is unlikely to be met in most studies of this type, including ours. However, assignment likelihoods are correlated with the hierarchical genetic structure typical of salmonids such that, if the source population is not in the baseline but a genetically similar population is, the unknown individual will likely be assigned to the correct hierarchical genetic group for the actual source population. The groups to which we assigned our samples were determined by examining the accuracy of different configurations with leave-one-out cross-validation analyses.

Once the genetic stock groups were established, we employed a 2-tiered approach to determine the genetic stock origin of each ocean-caught steelhead. First, we used the program ONCOR to assign individuals to 1 of 7 genetic stock groups from a baseline of 131 SNP loci from 148 populations sampled in an area from the Central Valley of California to Puget Sound, Washington. This first tier of GSI assignments provided us with the resolution adequate for determining whether samples originated from the Columbia River Basin or from another region. The accuracy of this baseline was estimated by using the leave-one-out method as implemented in ONCOR. This leave-one-out method removes an individual fish from the baseline and treats it like an individual with an unknown origin, while assigning it to a group by using the remaining individuals in the baseline. This procedure is repeated for all individuals in the baseline, and a running total of how many of the assignments were correct is used to estimate the accuracy of the baseline.

Second, samples that were assigned to the Columbia River genetic stock group during the first analysis were then analyzed with ONCOR by using a baseline of 180 SNP loci from 116 populations of the Columbia River (Hess et al. ${ }^{1}$, to determine to which of the 4 genetic stock groups of the Columbia River each of those fish belonged. The accuracy of this baseline was also tested by using the leave-one-out method.

Some of the assignments of fish sampled from the Columbia River were made by using the technique known as parentage-based tagging, with the software SNPPIT, vers. 1.0 (Anderson $\left.^{3}\right)$. Parentage-based tag-

\footnotetext{
${ }^{3}$ Anderson, E. C. 2010. Computational algorithms and user-friendly software for parentage-based tagging of $\mathrm{Pa}$ cific salmonids. Final report submitted to the Pacific Salmon
}

ging is accomplished by genotyping as many hatchery adult broodstock within a region as possible and then implementing parentage assignments to identify the offspring of those adults when they are sampled in a mixture of unknown individuals (Steele et al., 2013). Although we were not necessarily interested in knowing the hatchery of origin of our samples, this method can increase the accuracy of the GSI assignments because offspring are assigned directly to their parents rather than to a geographic region on the basis of their genotype frequencies. At the time of our analyses, parentage-based tagging data were available only for adults that spawned in 2009-2012 at hatcheries in the Snake River (data available from website, accessed January 2016).

\section{Stock distributions and catch}

Using the genetic stock assignments for each fish, we examined stock-specific distributions in our study area. To obtain a measure of steelhead relative abundance, we calculated values of stock-specific catch per unit of effort (CPUE) simply as the number of fish caught divided by the number of kilometers trawled. We then compared CPUE among years. In addition, we calculated the average CPUE for each stock for each year and then averaged those values across years to estimate an overall stock-specific CPUE, giving equal weight to all years.

Steelhead that originate from the Columbia River represent several distinct genetic stock groups and origins (hatchery and wild), but they all enter the ocean at close to the same location, the mouth of the Columbia River. To examine differences in early marine migration among these groups, latitude and longitude values were averaged for all fish originating from the same genetic stock group. Latitude and longitude values had been recorded for each trawl haul during sampling. These annual averages of latitude and longitude for each genetic stock group then were averaged over all years, to equally weight each year, and standard deviations were calculated. Differences in latitude also were converted to distance in kilometers (by using a conversion calculator available from the NOAA National Hurricane Center at website, accessed November 2018).

\section{Results}

\section{Genetic stock groups}

The genetic stock groups we chose for genetic assignments were those that provided the highest degree of geographic resolution, while still retaining high accuracy and close alignment with the distinct population segments identified in assessments completed as

Commission's Chinook Technical Committee (US Section), 43 p. [Available from website, accessed July 2018.] 
Table 2

Percentage of individuals correctly assigned to their stock of origin, determined by using leave-one-out simulations, for 7 genetic stock groups of steelhead (Oncorhynchus mykiss), ranging from the Central Valley of California to Puget Sound, Washington. The genetic stock groups in the left column represent the groups from which fish originated, and the genetic stock groups in the column heads identify the genetic stock group to which fish were assigned by using genetic stock identification.

\begin{tabular}{|c|c|c|c|c|c|c|c|}
\hline Genetic stock group & $\begin{array}{l}\text { Puget Sound } \\
\text { Strait of } \\
\text { Juan de Fuca }\end{array}$ & $\begin{array}{c}\text { Washington } \\
\text { coast }\end{array}$ & $\begin{array}{l}\text { Columbia } \\
\text { River }\end{array}$ & $\begin{array}{c}\text { Oregon } \\
\text { coast }\end{array}$ & $\begin{array}{l}\text { Northern } \\
\text { California }\end{array}$ & $\begin{array}{l}\text { Klamath } \\
\text { Mountains } \\
\text { Province }\end{array}$ & $\begin{array}{l}\text { Central } \\
\text { Valley, } \\
\text { California }\end{array}$ \\
\hline Puget Sound/Strait of Juan de Fuca & $90.3 \%$ & $6.6 \%$ & $2.3 \%$ & $0.8 \%$ & $0.0 \%$ & $0.0 \%$ & $0.0 \%$ \\
\hline Washington coast & $8.1 \%$ & $84.1 \%$ & $6.4 \%$ & $1.3 \%$ & $0.0 \%$ & $0.0 \%$ & $0.0 \%$ \\
\hline Columbia River & $0.3 \%$ & $0.3 \%$ & $99.2 \%$ & $0.1 \%$ & $0.0 \%$ & $0.0 \%$ & $0.0 \%$ \\
\hline Oregon coast & $2.3 \%$ & $4.7 \%$ & $6.3 \%$ & $86.7 \%$ & $0.0 \%$ & $0.0 \%$ & $0.0 \%$ \\
\hline Northern California & $0.0 \%$ & $0.0 \%$ & $0.0 \%$ & $0.0 \%$ & $100.0 \%$ & $0.0 \%$ & $0.0 \%$ \\
\hline Klamath Mountains Province & $0.0 \%$ & $0.0 \%$ & $0.0 \%$ & $0.0 \%$ & $0.0 \%$ & $100.0 \%$ & $0.0 \%$ \\
\hline Central Valley, California & $0.0 \%$ & $0.0 \%$ & $0.0 \%$ & $0.0 \%$ & $0.0 \%$ & $0.0 \%$ & $100.0 \%$ \\
\hline
\end{tabular}

\section{Table 3}

Percentage of individuals correctly assigned to their stock of origin, determined by using leave-one-out simulations, for 4 Columbia River genetic stock groups of steelhead (Oncorhynchus mykiss). The genetic stock groups in the left column represent the groups from which fish originated, and the genetic stock groups in the column heads identify which genetic stock groups fish were assigned to by using genetic stock identification.

\begin{tabular}{|c|c|c|c|c|}
\hline Genetic stock group & $\begin{array}{c}\text { Lower Columbia } \\
\text { River } \\
\text { summer run }\end{array}$ & $\begin{array}{c}\text { Lower Columbia } \\
\text { River } \\
\text { winter run }\end{array}$ & $\begin{array}{l}\text { Middle and } \\
\text { Upper Columbia } \\
\text { River/Lower } \\
\text { Snake River }\end{array}$ & $\begin{array}{l}\text { Middle and } \\
\text { Upper } \\
\text { Snake River }\end{array}$ \\
\hline Lower Columbia River summer run & $89.2 \%$ & $10.8 \%$ & $0.0 \%$ & $0.0 \%$ \\
\hline Lower Columbia River winter run & $5.4 \%$ & $93.4 \%$ & $1.0 \%$ & $0.2 \%$ \\
\hline Middle and Upper Columbia River/Lower Snake River & $0.1 \%$ & $0.1 \%$ & $91.4 \%$ & $8.4 \%$ \\
\hline Middle and Upper Snake River & $0.0 \%$ & $0.0 \%$ & $7.6 \%$ & $92.4 \%$ \\
\hline
\end{tabular}

required under the Endangered Species Act (Busby et al., 1996; NWFSC, 2015). The first-tier baseline, with 131 loci from 148 coast-wide populations, had high self-assignments within each reporting group (Table 2). The overall within-group self-assignment average was $94.1 \%$. The least accurate group for this configuration was the Washington coast group, with an average of $84.1 \%$. The majority of the incorrect assignments for this group were made to the Columbia River group.

The second-tier baseline, with 180 loci from 109 populations of the Columbia River, had an overall withingroup self-assignment accuracy of $91.9 \%$ (Table 3 ). The least accurate group for this baseline was the Lower Columbia River summer-run group, with an average of $89.2 \%$ and the majority of incorrect assignments made to the Lower Columbia River winter-run group.

Of our ocean-caught samples, 34 fish had been tagged previously with coded-wire tags, which provided identification of their hatchery of origin. These fish originated from 4 of our genetic stock groups and provided a further means to assess the accuracy of our baselines and genetic stock groups. Our GSI estimates agreed $100 \%$ with the stock origins indicated by the tags for those samples.

\section{Genetic stock identification}

During the surveys conducted in May, 490 steelhead were caught, with high variation in the number of fish caught among years (Table 4$)$. The majority $(68.8 \%)$ of the fish caught were marked, indicating that they had a hatchery origin. This proportion is an underestimate of the true proportion of fish with a hatchery origin in our sample, given that the marking rate of steelhead from hatcheries in the Columbia River was $83.2 \%$ during our sampling period (Regional Mark Processing Center, Regional Mark Information Database, available from website, accessed July 2017). Steelhead captured in the trawl hauls originated from 8 of the 10 genetic reporting groups, but the vast majority of them were from the Columbia River $(78.3 \%)$. Only one steelhead was identified as having originated from any of the 3 


\section{Table 4}

The number of juvenile steelhead (Oncorhynchus mykiss) caught each year from each genetic stock group, the number that were marked with a tag or fin clip, and the overall catch per unit of effort (CPUE) for each year in the period 2006-2012 and summarized over all sampling stations in a study area from Puget Sound, Washington, to the Central Valley of California.

\begin{tabular}{|c|c|c|c|c|c|c|c|c|c|c|c|}
\hline Year & $\begin{array}{c}\text { Total } \\
\text { number }\end{array}$ & $\begin{array}{l}\text { Puget } \\
\text { Sound/ } \\
\text { Strait of } \\
\text { Juan de } \\
\text { Fuca }\end{array}$ & $\begin{array}{c}\text { Washing- } \\
\text { ton } \\
\text { coast }\end{array}$ & $\begin{array}{c}\text { Lower } \\
\text { Columbia } \\
\text { River } \\
\text { summer } \\
\text { run }\end{array}$ & $\begin{array}{c}\text { Lower } \\
\text { Columbia } \\
\text { River } \\
\text { winter } \\
\text { run }\end{array}$ & $\begin{array}{c}\text { Mid and } \\
\text { Upper } \\
\text { Columbia } \\
\text { River } \\
\text { Lower } \\
\text { Snake } \\
\text { River }\end{array}$ & $\begin{array}{c}\text { Mid and } \\
\text { Upper } \\
\text { Snake } \\
\text { River }\end{array}$ & $\begin{array}{c}\text { Oregon } \\
\text { coast }\end{array}$ & $\begin{array}{c}\text { Central } \\
\text { Valley, } \\
\text { California }\end{array}$ & Marked & $\begin{array}{l}\text { Overall } \\
\text { CPUE }\end{array}$ \\
\hline 2006 & 234 & 2 & 16 & 33 & 44 & 82 & 54 & 3 & 0 & 193 & 2.095 \\
\hline 2007 & 45 & 5 & 11 & 2 & 19 & 5 & 0 & 2 & 1 & 17 & 0.273 \\
\hline 2008 & 72 & 4 & 23 & 4 & 9 & 12 & 16 & 4 & 0 & 40 & 0.446 \\
\hline 2009 & 41 & 4 & 8 & 3 & 8 & 8 & 10 & 0 & 0 & 29 & 0.274 \\
\hline 2010 & 46 & 1 & 10 & 6 & 18 & 7 & 3 & 1 & 0 & 27 & 0.397 \\
\hline 2011 & 38 & 2 & 9 & 3 & 11 & 8 & 4 & 1 & 0 & 23 & 0.173 \\
\hline 2012 & 14 & 0 & 0 & 1 & 1 & 5 & 7 & 0 & 0 & 8 & 0.151 \\
\hline
\end{tabular}

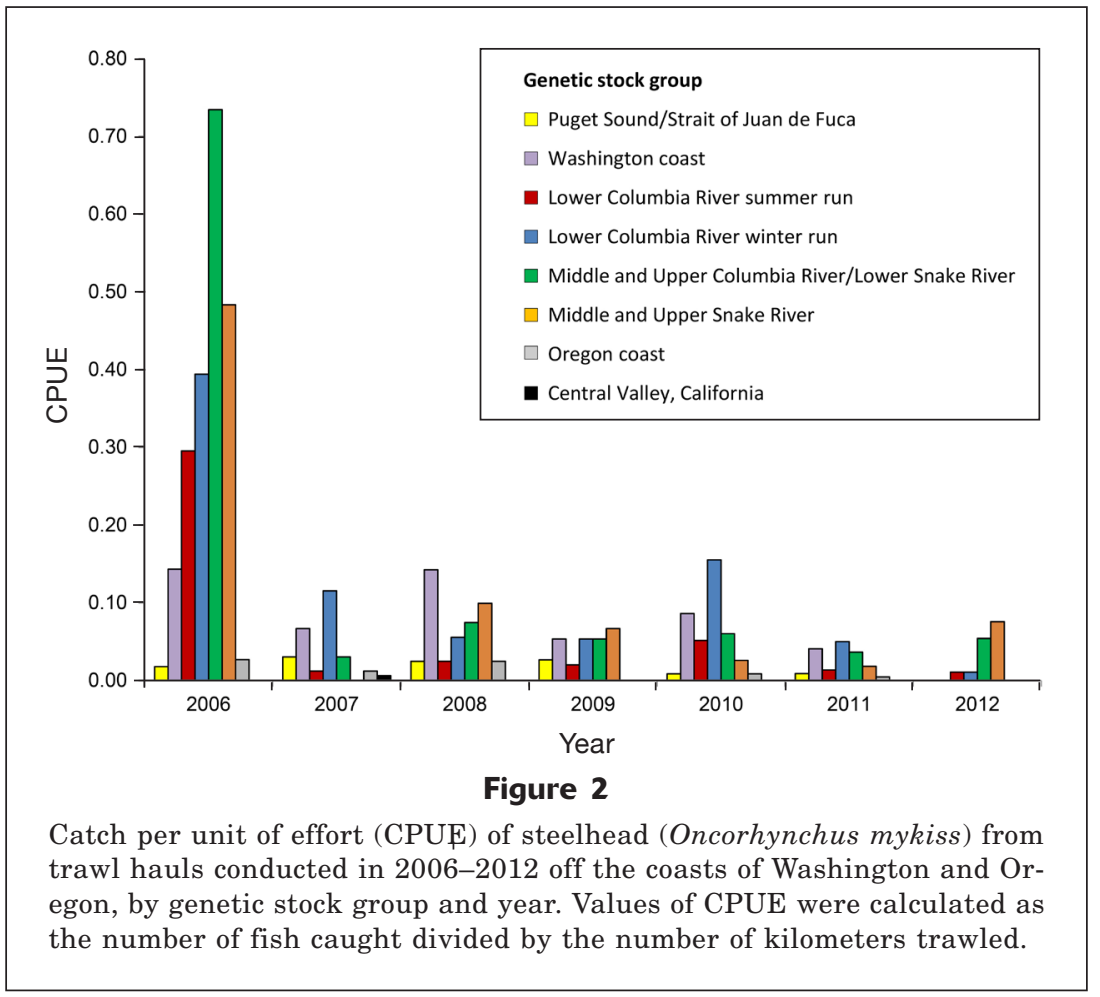

the genetic stock groups that included populations in the Snake River. The genetic stock group with the greatest CPUE value varied over the study period, but it was usually a group of the Columbia River, except in 2008, when the group from the Washington coast had the greatest CPUE value (Table 4).

There was also considerable variation in CPUE among transects of the trawl hauls each year (Fig. 3). In 2006 , the distribution of the steelhead caught was different than in all the other years because most of the steelhead were caught in the 3 southernmost transects, especially in those off Cape Meares, Oregon. Steelhead were caught on that transect in only one other year: 2012. The transect in Willapa Bay, Washington, was where most of the steelhead were caught in 2010, especially Lower Columbia River winter-run fish, whereas the greatest concentration of fish occurred on the northernmost transect, Father and Son, in 2011. The catch in other years was spread more evenly among transects.

On average, steelhead from each genetic stock group were found north of the mouth of the Columbia River (Fig. 4). Lower Columbia River steelhead were found farther north than other stock groups of the Columbia River. In particular, the Lower Columbia River winterrun steelhead were found farther north than all other stock groups, although there was considerable overlap in the standard deviations of latitudes among all groups. The greatest difference in latitude $(90 \mathrm{~km})$ was
There was considerable variation in CPUE among years (Fig. 2). The CPUE values in 2006 were considerably greater than those in any other year, especially for

ley of California). That individual was not included in subsequent analyses.

\section{Stock distributions and catch}




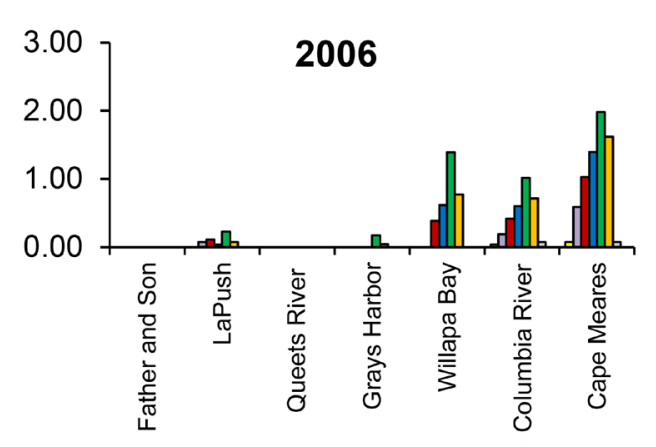

\section{Genetic stock group \\ $\square$ Puget Sound/Strait of Juan de Fuca \\ $\square$ Washington coast}

- Lower Columbia River summer run

$\square$ Lower Columbia River winter run

Middle and Upper Columbia River/Lower Snake River

$\square$ Middle and Upper Snake River

$\square$ Oregon coast

- Central Valley, California
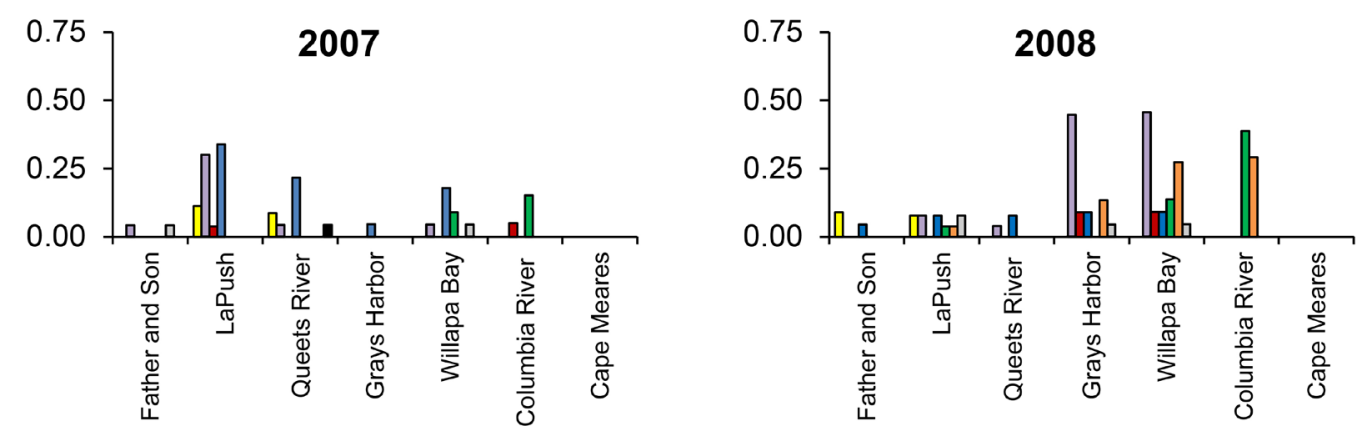

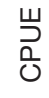
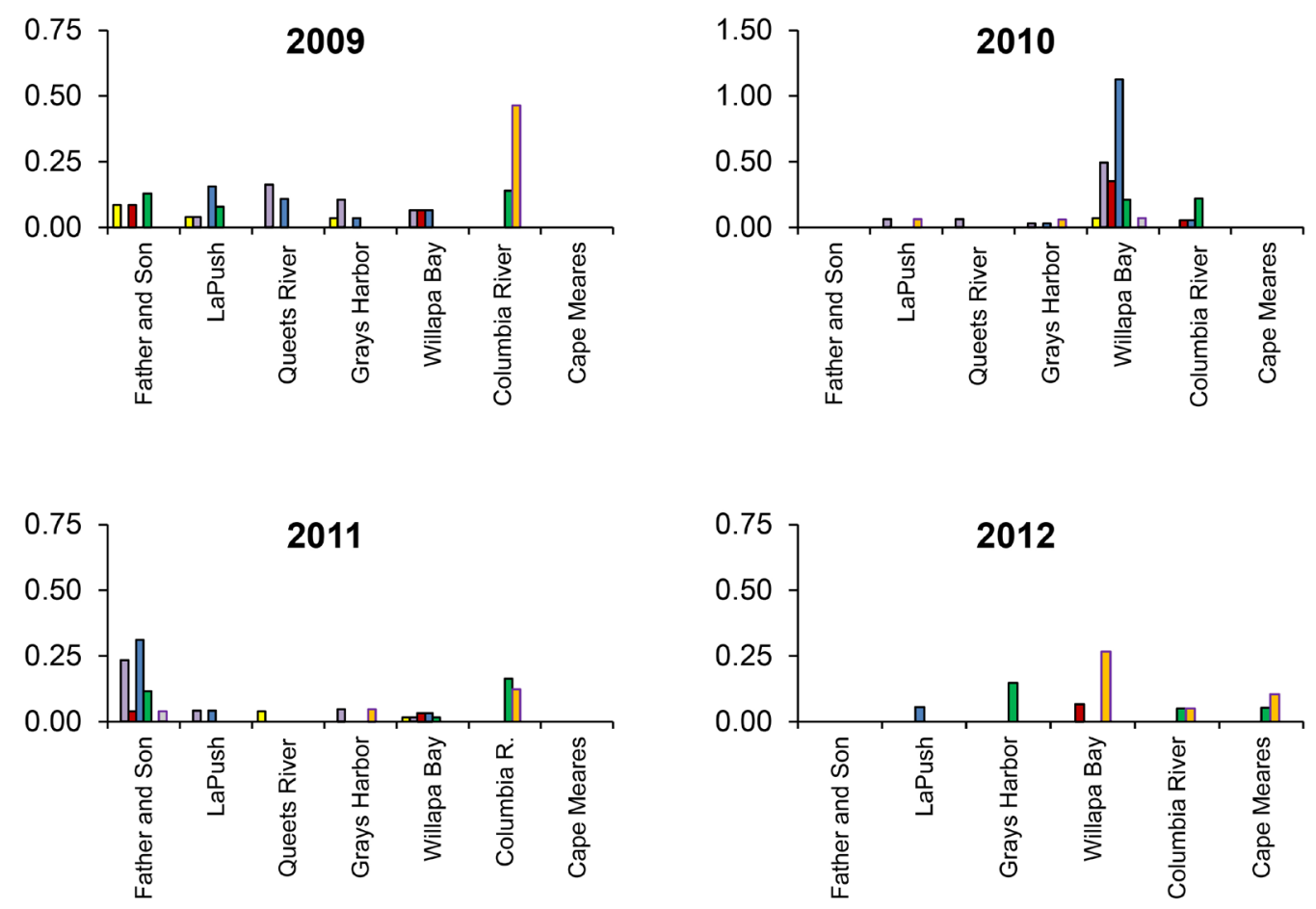

Transect

Figure 3

Catch per unit of effort (CPUE) of steelhead (Oncorhynchus mykiss) from trawl hauls conducted in 2006-2012 off the coasts of Washington and Oregon, by transect. Transects are arranged north to south on the x-axis. Note that the y-axis scale is different for 2006 and 2010. For transect locations, see Figures 1 and 4. 
between the Lower Columbia River winter-run and the Middle and Upper Snake River groups. The Lower Columbia River winter-run group also was found farther north $(44 \mathrm{~km})$ than the Lower Columbia River summerrun group. The average longitude values indicate that we tended to catch steelhead at our westernmost (farthest from shore) sampling stations.

\section{Discussion}

Using GSI, we examined the distribution of steelhead juveniles off the coast of Oregon and Washington during their early marine migration and found differences in relative abundance and distribution among genetic stocks and years. From this work, we provide the first published evidence of stock-specific distributions of juvenile steelhead from the Columbia River. Steelhead from the Lower Columbia River winter- and summerrun groups were found, on average, farther north than fish from other genetic stock groups of the Columbia River. The simplest explanation for this observation is a difference in the timing of marine entry among these groups. Lower Columbia River steelhead have been observed to migrate through the estuary earlier than other genetic stock groups of steelhead from the Columbia River (Weitkamp et al., 2015). Therefore, at the time of our sampling, they had been in the ocean for a longer period, giving them more time to travel north. We also observed that between the Lower Columbia River steelhead genetic stock groups, the winter-run fish were found farther north than the summer-run fish. Additional analysis of data from Weitkamp et al. (2015) revealed that, on average, Lower Columbia River winter-run steelhead passed through the estuary $3.1 \mathrm{~d}$ earlier than summer-run steelhead, a finding that could explain why we found them farther north, but this difference in timing was not significant $(t=1.52$, $P=0.203$ ).

Although our research focused on stocks of steelhead from the Columbia River, there were a few interesting results regarding other stocks. Of note is the presence of fish from the Oregon coast in our catches, indicating that not all steelhead from that area migrate directly to offshore waters before heading north, as has been generally accepted (Myers, 2018). Some of these fish may have migrated up to $300 \mathrm{~km}$ north before they entered our study area. However, given the low CPUE values for this stock, the majority of them may already have been offshore outside of our study area and the few that were caught likely were migrating closer to the coast. Also, in our study area, we caught steelhead that were assigned to the genetic stock group from Puget Sound and the Strait of Juan de Fuca, indicating that they did not migrate north immediately (we caught them at locations that were south of the entrance to the Strait of Juan de Fuca, through which they pass). However, the Chambers Creek hatchery steelhead stock, a stock that originated in Puget Sound, has been raised and released extensively by hatcheries in Washington, in-

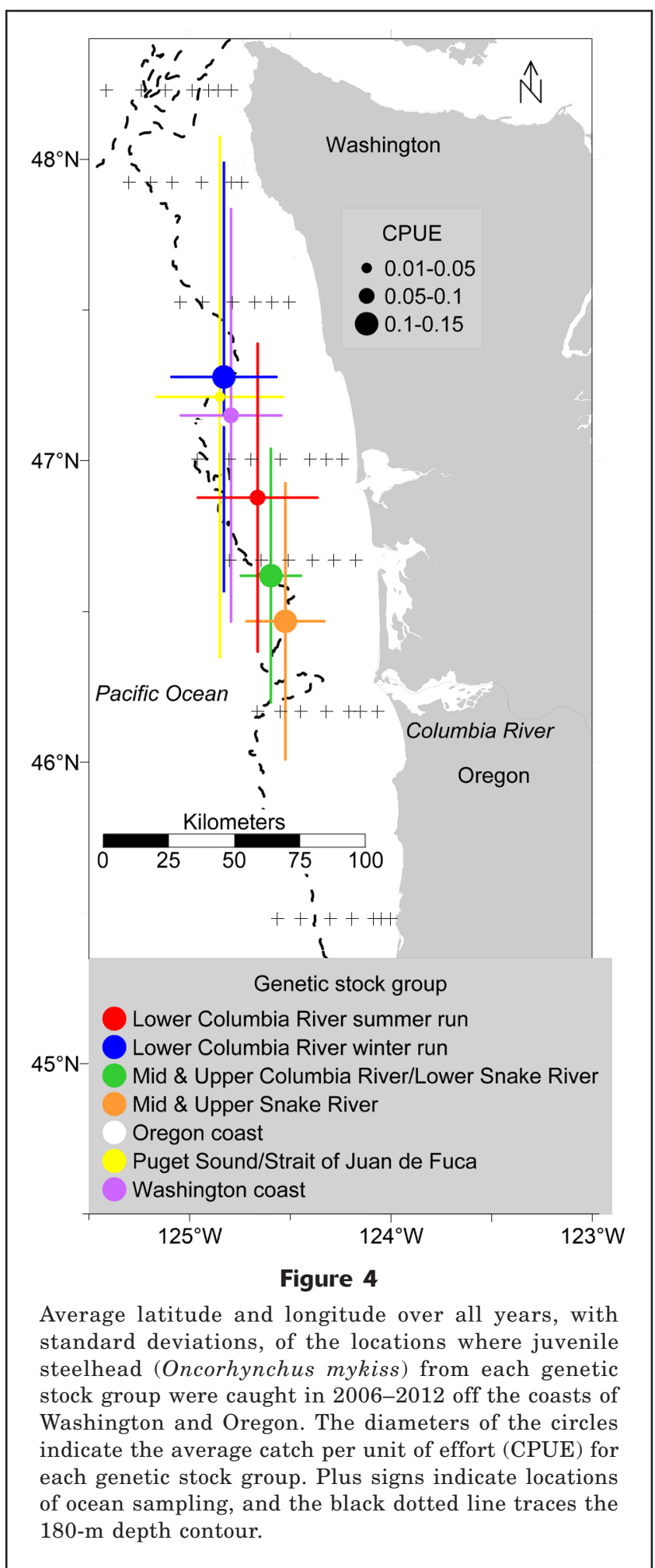

cluding those located on rivers of the Washington coast and the Lower Columbia River (Busby et al., 1996). Therefore, it is possible that the fish we caught were progeny of stock from Chambers Creek released into rivers not within the Puget Sound Basin. 
We observed a considerable difference in both CPUE and location of juvenile steelhead between 2006 and the other years of our study period. It is possible that some of the variability in our sampling success was a result of sampling essentially in the right place at the right time, a time and place that varies from year to year. For example, in 2007, we caught no steelhead from the Middle and Upper Snake River and very few steelhead from the Middle and Upper Columbia River or Lower Snake River. The numbers of releases of hatchery-reared steelhead from those areas in 2007 were similar to those in other years (Fish Passage Center, hatchery releases of steelhead during 2006-2016, available from website, accessed February 2017); therefore, the timing of our sampling may have resulted in our failure to catch fish from those stocks. We know that juvenile steelhead do not stay in our study area for long. McMichael et al. (2013) found evidence that juvenile steelhead from the Columbia River migrate away from the mouth of the Columbia River at a faster rate than Chinook salmon and that they exit the plume area soon after entering the ocean, mostly within $3 \mathrm{~d}$. In another study, few juvenile steelhead were caught in trawl hauls conducted 1 month later in June along the same transects used in our study (Daly et al., 2014). It's likely that annual variability in the timing of marine entry and quick migration away from coastal waters, evidenced by the fact that we caught most of our samples at the sampling stations farthest from shore, combined to cause variability in our sampling success.

A thorough evaluation of both freshwater and marine environmental drivers of migration behavior could help describe the interannual and inter-stock differences we found. Flow can influence river migration rate and, therefore, timing of ocean arrival. Temperature and food conditions can alter growth rates, resulting in disparity in size of fish among years or stocks and influencing migration behavior. Importantly, differences in survival can influence the spatial and temporal distributions of the surviving individuals, which are then represented in our catches. However, initial comparisons with some basic measures of environmental variables (river volume, river plume location and volume, and marine temperature and salinity) did not highlight obvious drivers of interannual and inter-stock abundance and distribution (data from these comparisons are not shown).

The baseline of genetic data that we assembled allowed us to identify stock-specific distributions of juvenile steelhead upon their entry into the ocean. The ability to identify the stock of origin of both tagged and untagged steelhead will be invaluable for future research into the possibility that forces that affect the survival of steelhead during early marine migration influence different genetic stock groups differently.

\section{Acknowledgments}

We thank the captain and crew of the F/V Frosti for providing a safe and professional sampling platform and the many people who assisted with sample collection efforts. Thanks also to B. Beckman, D. Teel, and L. Weitkamp for providing helpful reviews of previous versions of this manuscript.

\section{Literature cited}

Blankenship, S. M., M. R. Campbell, J. E. Hess, M. A. Hess, T. W. Kassler, C. C. Kozfkay, A. P. Matala, S. R. Narum, M. M. Paquin, M. P. Small, et al.

2011. Major lineages and metapopulations in Columbia River Oncorhynchus mykiss are structured by dynamic landscape features and environments. Trans. Am. Fish. Soc. 140:665-684. Crossref

Brodeur, R. D., W. T. Peterson, G. W. Boehlert, E. Casillas, M. H. Schiewe, M. B. Eldridge, S. T. Lindley, J. H. Helle, and W. R. Heard.

2000. A coordinated research plan for estuarine and ocean research on Pacific salmon. Fisheries 25(6):7-16. Crossref

Brodeur, R. D., J. P. Fisher, D. J. Teel, R. L. Emmett, E. Casillas, and T. W. Miller.

2004. Juvenile salmonid distribution, growth, condition, origin, and environmental and species associations in the Northern California Current. Fish. Bull. 102:25-46.

Brodeur, R. D., J. P. Fisher, R. L. Emmett, C. A. Morgan, and E. Casillas.

2005. Species composition and community structure of pelagic nekton off Oregon and Washington under variable oceanographic conditions. Mar. Ecol. Prog. Ser. 298:41-57. Crossref

Burgner, R. L., J. T. Light, L. Margolis, T. Okazaki, and S. Ito. 1992. Distribution and origins of steelhead trout $(\mathrm{On}$ corhynchus mykiss) in offshore waters of the North Pacific Ocean. Int. N. Pac. Fish. Comm., Bull 51, 95 p. [Available from website.]

Busby, P. J., T. C. Wainwright, G. J. Bryant, L. J. Lierheimer, R. S. Waples, F. W. Waknitz, and I. V. Lagomarsino.

1996. Status review of West Coast steelhead from Washington, Idaho, Oregon, and California. NOAA Tech. Memo. NMFS-NWFSC-27, 181 p.

Daly, E. A., J. A. Scheurer, R. D. Brodeur, L. A. Weitkamp, B. R. Beckman, and J. A. Miller.

2014. Juvenile steelhead distribution, migration, feeding, and growth in the Columbia River estuary, plume, and coastal waters. Mar. Coast. Fish. 6:62-80. Crossref

Dawley, E. M., R. D. Ledgerwood, T. H. Blahm, C. W. Sims, J. T. Durkin, R. A. Kirn, A. E. Rankis, G. E. Monan, and F. J. Ossiander.

1986. Migrational characteristics, biological observations, and relative survival of juvenile salmonids entering the Columbia River estuary, 1966-1983, 256 p. Bonneville Power Admin., Portland, OR, and Northwest Alaska Fish. Sci. Cent., Natl. Mar. Fish. Serv., Seattle, WA. [Available from website.]

Furey, N. B., S. P. Vincent, S. G. Hinch, and D. W. Welch.

2015. Variability in migration routes influences early marine survival of juvenile salmon smolts. PLoS ONE 10(10):e0139269. Crossref

Hare, S. R., and R. C. Francis.

1995. Climate change and salmon production in the northeast Pacific Ocean. In Climate change and northern fish populations (R. J. Beamish, ed.), p. 357-372. Can. Spec. Publ. Fish. Aquat. Sci. 121. 
Kalinowski, S. T., K. R. Manlove, and M. L. Taper.

2007. ONCOR: a computer program for genetic stock identification. Montana State Univ., Bozeman, MT. [Available from website, accessed January 2009.]

Matala, A. P., M. W. Ackerman, M. R. Campbell, and S. R. Narum.

2014. Relative contributions of neutral and non-neutral genetic differentiation to inform conservation of steelhead trout across highly variable landscapes. Evol. App. 7:682-701. Crossref

McMichael, G. A., A. C. Hanson, R. A. Harnish, and D. M. Trott.

2013. Juvenile salmonid migratory behavior at the mouth of the Columbia River and within the plume. Anim. Biotel. 1:1-14. Crossref

Myers, K. W.

2018. Ocean ecology of steelhead. In The ocean ecology of Pacific salmon and trout (R. J. Beamish, ed.), p. 779904. Am. Fish. Soc., Bethesda, MD.

NWFSC (Northwest Fisheries Science Center).

2015. Status review update for Pacific salmon and steelhead listed under the Endangered Species Act: Pacific Northwest, 351 p. [Available from website, accessed July 2018.]

Pearcy, W. G.

1992. Ocean ecology of North Pacific salmonids, 179 p. Univ. Wash. Press, Seattle, WA.

Quinn, T. P., and K. W. Myers.

2004. Anadromy and the marine migrations of Pacific salmon and trout: Rounsefell revisited. Rev. Fish Biol. Fish. 14:421-442. Crossref
Rannala, B., and J. L. Mountain.

1997. Detecting immigration by using multilocus genotypes. Proc. Natl. Acad. Sci. U.S.A. 94:9197-9201. Crossref

Steele, C. A., E. C. Anderson, M. W. Ackerman, M. A. Hess, N. R. Campbell, S. R. Narum, and M. R. Campbell.

2013. A validation of parentage-based tagging using hatchery steelhead in the Snake River basin. Can. J. Fish. Aquat. Sci. 70:1046-1054. Crossref

Teel, D. J., B. J. Burke, D. R. Kuligowski, C. A. Morgan, and D. M. Van Doornik.

2015. Genetic identification of Chinook salmon: stock-specific distributions of juveniles along the Washington and Oregon coasts. Mar. Coast. Fish. 7:274-300. Crossref

Van Doornik, D. M., D. J. Teel, D. R. Kuligowski, C. A. Morgan, and E. Casillas.

2007. Genetic analyses provide insight into the early ocean stock distribution and survival of juvenile coho salmon off the coasts of Washington and Oregon. North Am. J. Fish. Manage. 27:220-237. Crossref

Weitkamp, L. A., P. J. Bentley, and M. N. C. Litz.

2012. Seasonal and interannual variation in juvenile salmonids and associated fish assemblage in open waters of the lower Columbia River estuary. Fish. Bull. 110:426-450.

Weitkamp, L. A., D. J. Teel, M. Liermann, S. A. Hinton, D. M. Van Doornik, and P. J. Bentley.

2015. Stock-specific size and timing at ocean entry of Columbia River juvenile Chinook salmon and steelhead: implications for early ocean growth. Mar. Coast. Fish. 7:370-392. Crossref 